Uşak Üniversitesi Sosyal Bilimler Dergisi

$2015,8 / 4$

\title{
Doğayla İlişkili Olma Ölçeğinin İlk Psikometrik Bulguları ve Öz- Aşkınlıkla İlişkisi
}

\author{
Hakan SARIÇAM* \\ Süleyman Hilmi ŞAHINN*
}

\section{Öz}

Bu çalışmada Doğayla İlişkili Olma Ölçeğinin Türkçe adaptasyon çalışması sunularak, ön-psikometrik bulguları incelenmiştir. Buna ek olarak doğayla ilişkili olma ve öz-aşkınlık arasındaki ilişkiye değinilmiştir. Açıklayıcı faktör analizi uygulandıktan sonra ölçüt geçerliği çalışması yapılmıştır. Ölçüt geçerliği çalışması için Yeni Ekolojik Paradigma Ölçeği kullanılmıştır. Ayrıca iç tutarlık güvenirlik ve test-tekrar test güvenirliği de sınanmıştır. Açıklayıcı faktör analizi sonucunda 21 maddelik tek faktörlü bir yapı elde edilmiş ve bu tek boyutlu yapı toplam varyansın \%38.71'ini açıklamaktadır. Faktör yükleri .30 ile .69 arasında sıralanmaktadır. Benzer ölçek geçerliği çalışmasında Doğa İle İlişkili Olma Ölçeği ile Yeni Ekolojik Paradigma Ölçeği arasında pozitif ilişki bulunmuştur. Ölçeğin Cronbach Alfa iç tutarlık güvenirlik katsayısı .76 olarak hesaplanmıştır. Test tekrar test güvenirlik katsayısı .68 , düzeltilmiş madde toplam korelasyon değerlerinin .29 ile .61 arasında sıralandığı gözlenmiştir. İkinci çalışmada ise doğayla ilişkili olma ile öz-aşkınlık arasında pozitif ilişki bulunmuştur. Çalışma bulguları ilgili literatür ışığında tartışılmıştır.

Anahtar Kelimeler: Doğayla İlişiklik, Çevre, Ölçek, Öz-Aşkınlık.

\section{The First Psychometric Properties of Turkish Version of the Nature} Relatedness Scale-21 (NRS-21) and Its' Relation to Self-transcendence

\section{Abstract}

This paper presented the Turkish version of the Nature Relatedness Scale, examined its pre-psychometric properties. Besides, the relationship between nature relatedness and self-transcendence was adverted. Exploratory factor analysis was conducted, followed by concurrent validity. New Ecological Paradigm (NEP) Scale was used for concurrent validity. In

* Dumlupınar Üniversitesi, Eğitim Fakültesi, Rehberlik ve Psikolojik Danışmanlık ABD, hakan.saricam@dpu.edu.tr

** Dumlupınar Üniversitesi, Eğitim Fakültesi, Sosyal Bilgiler Öğretmenliği ABD, suleyman.sahin@dpu.edu.tr 
addition, the instrument's internal consistency and re-test reliability were proved. Results explanatory factor analyses demonstrated that 21 items yielded one-factor, and that the uni-dimensional model was explained $38.71 \%$ of total variance. Factor loadings ranged from .30 to .69. In the concurrent validity significant positive relationship was found between NR21 Scale and NEP Scale. Cronbach Alpha internal consistency coefficients were found as .76 for scale. Moreover, test-retest reliability coefficient was .68 and corrected item-total correlations ranged from .29 to .61. In second study, nature relatedness has positive relationship with self-transcendence. The results were discussed in the light of the related literature.

Keywords: Nature Relatedness, Environment, Scale, SelfTranscendence.

\section{Giriş}

Her yıl termik ya da nükleer enerji santrallerinin kurulması, birçok devasa gökdelenlerin inşa edilmesi, $\mathrm{AVM}^{\prime}$ lerin sayısının günden güne artması vs. yaşamımız için birçok katkı sağladığı şüphesizdir. Fakat beraberinde bir o kadar da tahribatı ve çevre sorununu birlikte getirmektedir. Doğa ya da başka bir ifade ile çevre sorunlarını, sadece çevrenin kirletilmesi veya bilinçsizce kullanılması olarak değil daha geniş açıdan bakıldığında toplumsal, siyasal, ekonomik, kültürel, dini ve ahlaki boyutları da olan son derece karmaşık bir sorunlar yumağı olarak görmek daha doğru olacaktır (Gül, 2013). Doğa, insan eseri olmaksızın kendine özgü kural ve kanunlarla çalışan kâinat şeklinde tanımlandığı (Atalay, 2013) gibi, kendiliğinden doğmuş olup sanat ve kültür gibi insan düşüncesinin ortaya koyduğu varlıkların karışımdır (İzbırak, 1992) şeklinde de tanımlanmaktadır. İnsanlar yaşamlarının ilk anlarından itibaren doğanın kendilerine sunduğu imkânları kullanarak onlarla birlikte varlıklarını sürdürmektedirler. Doğadaki yaşanan olayların bireyler tarafından öğrenilmesi doğa insan ilişkisi açısından önemlidir. Doğayla geçirilen zaman bireylerde ruhsal rahatlama sağlamasını yanı sıra bedensel ve fonksiyonel faydalar da sağlamaktadır (Nisbet \& Zelenski, 2011). Bununla birlikte doğayla ilişkili olma birçok olumlu çevresel davranış ve tutumları da beraberinde getirmektedir (Zelenski \& Nisbet, 2014). Özellikle birçok ilimizde belediyelerce yapılan "hobi evleri" bunun en güzel örneklerindendir. Bu evler sayesinde birçok vatandaşımız şehrin gürültülü ve yoğun ortamından kurtularak doğayla iç içe bir yaşam sürmektedir.

İnsanlığın ortak mirası olan doğanın korunması gelecek nesillerin mutlu bir hayat sürmelerinde önem arz etmektedir. Doğanın kirletilmesinin 
engellenmesinde ve gerekli tedbirlerin alınmasında yapılacak ilk faaliyet bireylere hayatlarının ilk anlarından itibaren doğru ve tam bir çevre ve doğa eğitiminin verilmesidir. Doğayı tanımak, korumak ve farkındalık yaratmak açısından doğa eğitimi önemli fırsatlar yaratacaktır. Bu verilen eğitim ile bireylerde sağlam bir çevre koruma bilinci gelişmesi sağlanabilir (Köşger, 2013). Doğa eğitiminin en kısa tarifi "doğanın dilinin öğrenilmesi” dir. Fakat bu eğitimin sadece bilgi ve algı düzeyinde değil yaşantı düzeyinde yapılması etkili sonuçlar ortaya çıkartacaktır (Erdoğan 2005). Bir doğa eğitiminin yaşantı düzeyinde etkili olabilmesi için öncelikle katılımcıların kendini ne kadar doğanın bir parçası olarak görüp görmediği en az eğitim kadar önemlidir. Bu yüzden bireylerin doğaya aidiyet düzeylerini değerlendirecek ölçme araçlarının gerekliliği ortaya çıkmaktadır. Bu çalışmadaki hedeflerden biri alanyazına böyle bir ölçme aracı olan Doğayla İlişki Olma Ölçeğini kazandırmaktır.

Çalışmadaki diğer bir kavram ise öz-aşkınlıktır. Öz-aşkınlık yaşama geniş bakmaya yönelik çevre ve çevreye uyum farkındalığı sağlayan bilişsel olgunluk olarak tanımlanmaktadır (Reed, 2008:107, Akt. Sarıçam, 2013). Reed'in (2008) Öz Aşkınlık Teorisinde, öz aşkınlık: a) kendi iç sınırlarını aşma (bir felsefenin, bir değerin bir hayalin farkına varmanın ötesinde bir olgu), b) kişilerarası yaşama (bir çevre ve başkalarıyla ilişkili olma), c) zamansal düşünme (geçmiş ile gelecek gidişatında şimdiyi anlamaya entegre olmak), d) insanüstü düşünme (tipik olarak görülebilen dünyanın ötesinde boyutlara ulaşmak) kapasitesi olarak geçmektedir (Sarıçam, 2013).

Maslow'un ihtiyaçlar hiyerarşisi teorisinde birey, fizyolojik ihtiyaçlarını, güvenlik ihtiyaçlarını, bağlılık ve sevgi ihtiyaçlarını, saygı görme ihtiyacını, bilme ve anlama ihtiyacını, estetik ihtiyaçlarını, kendini gerçekleştirme ihtiyacını (Woolfolk (1993) gidererek nihai yaşam hedefine gerçek manada ulaşabilir. Fakat Vanagas ve Rakšnys (2014) ile Sarıçam'ın (2015) iddialarına göre ise insan kendini aşmadan yani öz-aşkınlığa ulaşmadan kendini gerçekleştirme süreci tamamlanamaz. Başka bir ifade ile öz-aşkınlık ihtiyaçlar basamağında kendini gerçekleştirmenin olgunlaşmış halidir denilebilir.

Levenson, Jennings, Aldwin ve Shiraishi (2005, s. 127) öz-aşkınlığın bir erdem olduğunu ifade etmişlerdir. Özellikle öz-aşkınlığın ben ile sınırlandırılamayacağını, kendiliğin sınırlarını aşarak geçmiş ile gelecek arasında bağ kurma hissi ve manevi bir duygu olduğunu iddia etmişlerdir. Öz-aşkınlığın ruhsal sağlık, yaşam doyumu üzerinde pozitif etkisinin olduğunu belirten birçok çalışma bulunmaktadır (Coward, 1996; Nygren ve diğerleri, 2005; Ramer, Johnson, Chan, \& Barrett, 2006; Reed, 1986; 1989; 1991a). 
Bu çalışmanın temel amacı Doğayla İlişkili Olma Ölçeğini Türkçe'ye uyarlayarak ölçeğin ilk psikometrik özelliklerini incelemektir. Araştırmanın diğer bir amacı ise doğayla ilişkili olma ve öz-aşkınlık arasındaki ilişki olup olmadığını saptamaktır.

\section{İlk Çalışma}

\section{Yöntem}

\section{Çalışma Grubu}

Çalışmanın ilk aşamasının çalışma grubunu Dumlupinar Üniversitesi Eğitim Fakültesinde 358 (212 kız, 146 erkek) üniversite öğrencisi oluşturmaktadır. Katılımcıların yaşları 17 ile 24 arasında değişmekte olup; yaş ortalamaları 20.96 olarak bulunmuştur. Ayrıca 161 öğrenci 1. Sınıf, 88 öğrenci 2. Sınıf'ta, 109 öğrenci 4. Sınıftadır.

\section{Veri Toplama Aracı}

Doğa İlişkililik Ölçeği-21 (Nature Relatedness (NR)-21): Nisbet, Zelenski ve Murphy (2009) tarafından yetişkinlerin doğayla ilişki düzeyini belirlemeye yönelik geliştirilen ölçek 21 madde ve 3 alt boyuttan (Doğayla ilişkide kendilik: 5, 7, 8, 12, 14, 16, 17, 21; Doğayla ilişkiye bakış açısı: 2, 3, 11, 15, 18, 19, 20; Doğayla ilişkide deneyimler: 1, 4, 6, 9, 10, 13) oluşmaktadır. Ölçek 5'li Likert ("1" Kesinlikle Katıllyorum, "2" Katılıyorum, "3" Kararsızım, "4" Katılmıyorum, "5" Kesinlikle Katılmıyorum) tipi olup; kendini değerlendirmeye yönelik bir ölçme aracıdır. Ölçekten toplam puan alınabildiği gibi alt boyutlara göre de puan alınabilmektedir; puanlama yapilırken 2., 3., 10., 11., 13., 14., 15., 18. maddeler ters kodlanmaktadır. Araştırmacılar tarafından ölçeğin yapı geçerliği için 831 üniversite öğrencisinden elde edilen verilere uygulanan açıklayıcı faktör analizi sonucu 3 boyutlu bir yapı elde edilmiştir. Madde faktör yükleri Doğayla ilişkide kendilik faktörü için .39 ile 87, Doğayla ilişkiye bakış açısı faktörü için .17 ile .52, Doğayla ilişkide deneyimler faktörü için .38 ile .81 arasında sıralanmaktadır. Chronbach alfa iç tutarlık güvenirlik katsayısı ölçeğin bütünü için .87, Doğayla ilişkide kendilik faktörü için .84, Doğayla ilişkiye bakış açısı faktörü için .66, Doğayla ilişkide deneyimler faktörü için .80. 6-8 hafta süresince yapılan tekrar uygulama sonucu test tekrar test korelasyon değerleri ölçeğin bütünü için .85, Doğayla ilişkide kendilik faktörü için .81, Doğayla ilişkiye bakış açısı faktörü için .65, Doğayla ilişkide deneyimler faktörü için .85 olarak bulunmuştur.

Yeni Ekolojik Paradigma Ölçeği-Revize Formu-RYEPÖ (Revised New Ecological Paradigm Scale- (R-NEP): Dunlap, Van Liere, Mertig ve Jones (2000) 
tarafından yetişkinlerin çevre inançlarını belirlemek için geliştirilen YEPÖ 15 madde 4 alt boyuttan oluşmaktadır. Beş'li Likert tipi (1=Tamamen Katılıyorum; $5=$ Kesinlikle Katılmıyorum) bir ölçme aracıdır. Bu yargıların sekiz tanesi $(1,3,5,7,9,11,13,15$ nolu yargılar) doğa merkezli bir görüşü savunan ifadelerdir. Kalan yedi tanesi ise $(2,4,6,8,10,12,14$ nolu yargilar) insan merkezli bir görüşü savunan ve çevreci yönelim aleyhine olan ifadelerdir. Ölçeğin Türkçeye uyarlaması ilk olarak Alnıaçık ve Koç (2009) tarafından yapılmış olup Kaiser-Meyer-Olkin (KMO) örneklem uygunluk katsayısı .684 bulunmuştur. Yapılan açıklayıcı faktör analizi sonucu toplam varyansın \%43.33'ünü açıklayan 4 faktörlü ("Ekolojik Tehlike", Teknolojik Üstünlük”, “Doğanın Gücü”, "İnsan Üstünlügü̈”) bir model elde edilmiştir. Erkal, Kılıç ve Şahin'in (2012) yapmış olduğu uyarlama çalışmasında 213 üniversite öğrencisinden elde edilen verilere yönelik faktör analizi uygulanmış olup ölçeğin özdeğeri 1 'den büyük ve toplam varyansın \%74'ünü açıklayan tek faktör altında toplandığı tespit edilmiştir. Bartlett's testi sonucu, faktör analizinin uygulanabileceğini ortaya koymuş $\left(\chi^{2}=1132.6\right.$; $\mathrm{p}<.001)$ ve hesaplanan $\mathrm{KMO}$ değeri $=.854$ örneklem hacminin yeterli düzeyde olduğunu göstermiş̧tir. Cronbach Alfa değeri 15 madde tek faktörlü model olarak .754 olarak hesaplanmıştır (Erkal, Kılıç, \& Şahin, 2012).

\section{İşlem}

Öncelikle Doğa İlişkilik Ölçeğinin uyarlama çalışması için ölçeği geliştirenlerden biri olan Elizabeth K. NISBET ile e-posta yoluyla iletişim kurulmuş ve ölçeğin uyarlanabileceğine ilişkin gerekli izin alınmıştır. Türkçeye çevrilme süreci belli aşamalardan oluşmaktadır. Öncelikle ölçek İngiliz Dili ve Edebiyatı bölümü mezunu 3 dil uzmanı tarafından Türkçeye çevrilmiş ve daha sonra bu Türkçe formlar tekrar İngilizceye çevrilerek her iki dili bilen 29 kişiye uygulama yapılarak bu iki form arasındaki tutarlılık incelenmiştir. Üç dil uzmanı, elde ettikleri Türkçe formlar üzerinde tartışarak anlam ve gramer açısından gerekli düzeltmeleri yapmış ve denemelik Türkçe form elde edilmiştir. Son aşamada bu form, coğrafya eğitimi, psikoloji ve psikolojik danışma ve rehberlik alanındaki 3 alan uzmanına inceletilerek görüşleri doğrultusunda bazı değişiklikler yapıldıktan sonra bir uygulama formu oluşturulup katılımcılara uygulanmıştır. Elde edilen veriler bilgisayar ortamına aktarıldıktan sonra paket programı aracılığıyla maddelere açıklayıcı faktör analizi (AFA), ölçüt geçerliği, güvenirlik ve madde analizleri yapılmıştır. 


\section{Bulgular}

\section{Dilsel Eşdeğerlik}

İngilizce ve Türkçeyi bilen 29 kişiye iki hafta arayla yapılan uygulamada Türkçe ve İngilizce formlar arasında $r=.79$ ilişki bulunmuştur.

\section{Yapı Geçerliği}

Açıklayıcı faktör analizi. Ölçeğin yapı geçerliği için ilk çalışmada 358 öğrenciden elde edilen verilerin faktör analizine uygunluğunu tespit etmek amacıyla Kaiser-Meyer-Olkin (KMO) katsayısı hesaplanmış ve Barlett Spehericity testi yapılmıştır. Verilerin faktör analizine uygunluğu için KMO .60 'dan yüksek ve Barlett testinin anlamlı çıkması gerekmektedir (Büyüköztürk, Akgün, Kahveci, ve Demirel, 2004). Yapılan analiz sonucu KMO örneklem uygunluk katsayısı .77, Bartlett Sphericity testi $\chi^{2}$ değeri 901.767 ( $\mathrm{p}<.001, \mathrm{sd}=195)$ bulunmuştur. Ölçeğin yetişkinlerden oluşan çalışma grubunda faktör yapısını ortaya koymak üzere açılayıcı faktör analizi (AFA) yapılmıştır. AFA yapılırken maddeler serbest bırakılmış ve özdeğeri 1'in üzerinde 6 faktör elde edilmiştir. Daha sonra yatay eksen (Scree Plot) grafiğinde ölçeğin 3 boyutlu olduğu gözlenmiştir. AFA yeniden yapılmış ve 3 faktörle sınırlandırılmıştır. Analiz sonucunda toplam varyansın \%47.38' ini açıklayan ölçeğin orijinaline uygun 3 faktörlü bir yapı elde edilmiştir. Fakat bazı maddelerin farklı iki faktörde yer almasından dolayı AFA tekrar uygulanmış ve bu sefer maddeler tek faktörle sınırlandırılmış (maddeler tek faktörle sınırlandırırken Nisbet, Zelenski ve Murphy (2009) çalışmasından yola çıkılmıştır), toplam varyansın \%38.71'ini açılayan bir yapı elde edilmiş ve sonuçlar Tablo 1'de verilmiştir. Bu bulgulara göre ölçeğin madde faktör yapısının Türk kültürüne uygun olduğu fakat maddelerin doğrulanması gerektiği sonucuna ulaşılmıştır. 
Tablo 1. AFA faktör yükleri ve varyans değeri

\begin{tabular}{cccc}
\hline Madde & Faktör yükü & Madde & Faktör yükü \\
\hline $\mathbf{1}$ & .43 & $\mathbf{1 2}$ & .55 \\
$\mathbf{2}$ & .36 & $\mathbf{1 3}$ & .31 \\
$\mathbf{3}$ & .30 & $\mathbf{1 4}$ & .33 \\
$\mathbf{4}$ & .31 & $\mathbf{1 5}$ & .35 \\
$\mathbf{5}$ &, 35 & $\mathbf{1 6}$ & .51 \\
$\mathbf{6}$ & .38 & $\mathbf{1 7}$ & .49 \\
$\mathbf{7}$ & .44 & $\mathbf{1 8}$ & .47 \\
$\mathbf{8}$ &, 49 & $\mathbf{. 1 9}$ & .66 \\
$\mathbf{9}$ & .32 & $\mathbf{2 0}$ & .32 \\
$\mathbf{1 0}$ & .34 & $\mathbf{2 1}$ & .47 \\
$\mathbf{1 1}$ & .69 & & \\
Toplam varyans (38.71) & & &
\end{tabular}

Tablo 1 incelendiğinde toplam varyansın \%38.71'ini açıklamaktadır. Madde faktör yükleri .30 ile .69 arasında sıralanmaktadır.

\section{Ölçüt geçerliği}

Ölçeğin benzer ölçek geçerliği çalışmasında Doğayla İlişkilik Ölçeği ile Yeni Ekolojik Paradigma Ölçeği arasında korelasyon değeri $r=.61$ bulunmuştur.

\section{Güvenirlik}

Ölçeğin güvenirlik çalışmalarında Cronbach alfa iç tutarlık güvenirlik katsayısı ölçeğin bütünü için .76 olarak hesaplanmıştır. Ayrıca 18 gün aralıklı test-tekrar test korelasyon katsayısı ölçeği bütünü için $r=.68$ olarak hesaplanmıştır.

\section{Madde analizi}

Ölçeğin düzeltilmiş madde toplam korelasyon katsayıları .29 ile .61 arasında siralanmakta olup; alt-üst $\% 27$ değerleri anlamlı bir şekilde farklılaşmaktadır. 


\section{İkinci Çalışma}

\section{Yöntem}

\section{Çalışma Grubu}

İkinci çalışmanın katılımcılarını Dumlupınar Üniversitesi Eğitim Fakültesi Formasyon Eğitimi Sertifika Programına devam eden 284 birey oluşturmaktadır. Katılımcılar 23 ile 41 yaş arasında değişmekte olup; yaş ortalaması 28.28 olarak hesaplanmıştır.

\section{Veri Toplama Araçları}

Doğayla İlişkilik Ölçeği: Ölçeğin Türkçe uyarlaması Sarıçam ve Şahin tarafından yapılmış olup; 21 madde tek boyuttan oluşmaktadır. Yukarıda ön psikometrik özellikleri incelenmiş olan ölçeğin yetişkinlerin doğayla ilişki düzeylerini değerlendirme kullanılabileceği kanısına varılmıştır.

Öz-Aşkınlık Ölçeği: Bireylerin aşkınlık düzeylerini belirlemek için Reed (1991a) tarafından geliştirilen 15 maddelik Öz aşkınlık Ölçeği Sarıçam (2015) tarafından Türkçeye adapte edilmiştir. Ölçeğin yapı geçerliği için uygulanan açıklayıcı faktör analizi sonucu maddeler orijinal formla uygun olarak tek boyutta toplanmıştır. Daha sonra yapılan doğrulayıcı faktör analizi sonucu 15 maddenin tek boyuttaki uyum indeksi değerleri $\left(\chi^{2} / \mathrm{sd}=1.76, \mathrm{RMSEA}=.062, \mathrm{CFI}=.97, \mathrm{GFI}=.94, \mathrm{IFI}=.97, \mathrm{NFI}=.96, \mathrm{RFI}=.95\right.$ ve $\mathrm{SRMR}=.042$ ) olarak bulunmuştur. Ölçeğin faktör yükleri .35 ile .57 arasında sıralanmaktadır. Ölçüt geçerliği çalışmasında öz-aşkınlık ile yaşam anlamı arasında pozitif ilişki, depresyon, anksiyete ve stres ile negatif ilişkiler olduğu görülmüştür. Cronbach alfa iç tutarlılık güvenirlik katsayısı .87; testtekrar test korelasyon katsayısı .80 olarak bulunmuştur. Ayrıca düzeltilmiş madde-toplam korelasyonlarının .34 ile .57 arasında sıralandığ görülmüştür. Bu sonuçlara dayanarak ölçeğin geçerli ve güvenilir bir şekilde bu çalışmada kullanılabileceğine karar verilmiştir.

\section{İşlem}

Bu aşamada Doğayla İlişkilik Ölçeği, Öz-Aşkınlık Ölçeği ve Kişisel Bilgi Formundan oluşan uygulama paketi 284 katılımcıya, ders dışında araştırmacılar biri tarafından bizzat uygulanmıştır. Uygulamaları yapmadan önce gerekli açıklamalar yapılmış ve katılımcılara gönüllülük ilkesi tekrar hatırlatılmış ve 15 dakikalık uygulamadan sonra dağıtılan formlar tekrar toplanmıştır. Bilgisayar ortamına aktarılan veriler normal dağılım sergilemediğinden yaşa göre doğayla ilişkili olma ve öz-aşkınlık düzeylerini karşılaştırmak için Kruskal-Wallis Testi, değişkenler arasındaki ilişki düzeyini saptamak için Sperman korelasyon analizi uygulanmıştır. 


\section{Bulgular}

\section{Yaşa göre doğayla ilişkili olma ve öz-aşkınlık}

Katılımcıların doğayla ilişkili olma ve öz-aşkınlık puanlarının yaşa göre farklılaşıp farklılaşmadığını tespit etmek için öncelikle yaşlar kategorilere ayrılmış ve daha sonra Kruskal-Wallis Testi uygulanmıştır, sonuçlar Tablo 2'de verilmiştir.

Tablo 2. Üst Biliş Puanlarının İllere Göre Kruskal Wallis H Testi Sonuçları

\begin{tabular}{llcclccc}
\hline & Yaş & $\mathrm{N}$ & $\overline{\mathrm{X}}$ & $\begin{array}{l}\text { Sira } \\
\text { ortalaması }\end{array}$ & $\mathrm{Sd}$ & $\chi^{2}$ & $\mathrm{p}$ \\
\cline { 2 - 8 } & $\begin{array}{l}23-28 \\
\text { arası }\end{array}$ & 128 & 52.58 & 86.14 & & & \\
$\begin{array}{l}\text { Doğayla } \\
\text { ilişkili } \\
\text { olma }\end{array}$ & $\begin{array}{l}29-35 \\
\text { arası }\end{array}$ & 97 & 71.55 & 169.89 & & & \\
& $\begin{array}{l}36 \\
\text { üzeri }\end{array}$ & 59 & 82.02 & 219.74 & 2 & 123.33 & .00 \\
& Toplam & 284 & 65.17 & & & & \\
& $\begin{array}{l}\text { 23-28 } \\
\text { arası }\end{array}$ & 128 & 31.12 & 64.55 & & & \\
& $\begin{array}{l}\text { 29-35 } \\
\text { arası }\end{array}$ & 97 & 49.89 & 196.55 & & & \\
Öz- & & & & 2 & 214.44 & .00 \\
aşkınlık & $\begin{array}{l}\text { 36 } \\
\text { üzeri }\end{array}$ & 59 & 51.37 & 222.76 & & & \\
& Toplam & 284 & 41.71 & & & & \\
\hline
\end{tabular}

${ }^{*} \mathrm{p}<0.05$

Tablo 2 incelendiğinde 36 ve üzeri yaşa sahip olanların doğayla ilişkili olma sıra ortalama puanı $(\overline{\mathrm{X}}=219.74), 29-35$ yaş arası olanların sıra ortalama puanından (169.89) ve 23-28 yaş arası olanların sıra ortalama puanından $(\overline{\mathrm{X}}=86.14)$ yüksektir; bu farklılık istatistiksel olarak anlamlıdır. Ayrıca 36 ve üzeri yaşa sahip olanların öz-aşkınlık sıra ortalama puanı $(\bar{X}=$ 222.76), 29-35 yaş arası olanların sıra ortalama puanından $(\bar{X}=196.55)$ ve 2328 yaş arası olanların sıra ortalama puanından $(\overline{\mathrm{X}}=64.55)$ yüksektir; bu farklılık istatistiksel olarak anlamlıdır. Başka bir ifadeyle yaş arttıkça doğayla ilişkili olma ve öz-aşkınlık artmaktadır. 


\section{Korelasyon analizi}

Doğayla ilişkili olma ile öz-aşkınlık arasında ilişkiyi tespit etmek için Spearman korelasyon analizi yapılmış ve sonuçlar Tablo 3'te gösterilmiştir.

Tablo 3. Açıklayıcı değerler, Cronbach alfa ve korelasyon değerleri

\begin{tabular}{lll}
\hline Değişkenler & $\mathbf{1}$ & $\mathbf{2}$ \\
\hline 1. Doğayla ilişkili olma & 1 & \\
2. Öz-aşkınlık & $.61^{* *}$ & 1 \\
\hline Ortalama & 65.17 & 41.74 \\
Standart sapma & 18.74 & 11.77 \\
Cronbach $\alpha$ & .74 & .82 \\
\hline
\end{tabular}

${ }^{* *} \mathrm{p}<.01$

Tablo 3 incelendiğinde doğayla ilişkili olma ve öz-aşkınlık arasında $\mathrm{p}<.01$ önem düzeyinde $\left(\mathrm{S}_{\mathrm{r}}=.61\right)$ pozitif ilişki tespit edilmiştir. Başka bir ifadeyle öz-aşkınlık arttıkça doğayla ilişkili olma düzeyi de artmaktadır.

\section{Tartışma ve Öneriler}

$\mathrm{Bu}$ çalışmada yetişkinlerin doğayla ilişkili olma düzeylerini genel manada değerlendirmeye yönelik Doğayla İlişkili Olma Ölçeğinin Türkçeye uyarlayarak; ön psikometrik bulgularını incelemek amaçlanmıştır. Bu amaç doğrultusunda Doğayla İlişkili Olma Ölçeğinin geçerliği, faktör analizi, ayırt edici geçerlik ve benzer ölçek geçerliği ile belirlenmiştir. Faktör analizi açıklayıcı faktör analizi (AFA) şeklinde yapılmıştır. AFA uygulanmasının nedeni Doğayla İlişkili Olma Ölçeğinin orijinal formunun faktör yapısının Türk örnekleminde değerlendirmektir (Büyüköztürk vd., 2004; Sümer, 2000). AFA sonucunda faktör yükleri literatürde kabul edilebilir değer olan .30' dan (Büyüköztürk, 2012; Çokluk, Şekercioğlu ve Büyüköztürk, 2012) yüksektir. Ayırt edici geçerlik çalışması sonucunda ilk yetişkin ve orta yetişkinlik döneminde bulunan bireyleri birbirinden anlamlı düzeyde ayırt ettiği görülmüştür. Uyum geçerliği (ölçüt geçerliği) çalışması sonucunda ise ölçeğin geçerli olduğu sonucuna varılmıştır. Doğayla İlişkili Olma Ölçeğinin güvenirlik çalışmaları sonuçlarına bakıldığında ise Cronbach-alfa iç tutarlık güvenirlik ile test-tekrar test yöntemiyle elde edilen korelasyon katsayılarının kabul edilebilir düzeyde olduğu görülmektedir. Alanyazında Cronbach-alfa iç tutarlık güvenirlik katsayısı minimum değeri .70; 
düzeltilmiş madde toplam korelasyon değerlerinin .30 kriterinden büyük olması (Erkuş, 2012) Doğayla İlişkili Olma Ölçeğinin psikolojik ölçme aracı geliştirme ve uyarlama kriterlerine uygun olduğunu göstermektedir. Ölçeğin orijinal formu ile karşılaştırıldığında Türkçe versiyonun madde faktör yükleri daha düşük çıkmıştır. Buna ek olarak ölçeğin Çek versiyonunda, 357 üniversite öğrencisinden elde edilen verilere uygulanan açıklayıcı faktör analizi sonucunda üç faktörlü bir yapı elde edilmiştir. Bu modelin Chronbach alfa iç tutarlık güvenirlik katsayısı ölçeğin bütünü için .84, Doğayla ilişkide kendilik faktörü için .76, Doğayla ilişkiye bakış açısı faktörü için .43, Doğayla ilişkide deneyimler faktörü için .72. (Franěk, 2012). $\mathrm{Bu}$ bulgular yapılan bu çalışmanınkinden daha iyi bulgulara sahip olduğunu göstermektedir. Fakat Franěk (2012), Nisbet, Zelenski ve Murphy (2009) ile Nisbet ve Zelenski (2013) çalışmalarında önerilen ölçeğin tek boyutlu yapıda kullanılmasıdır. Bu çalışmada bu öneri dikkate alınmış ve ölçeğin tek faktörlü yapıyla kullanılabileceği kararlaştırılmıştır.

Doğayla İlişkili Olma Ölçeğinin yetişkinlerin doğayla ilişki düzeyi ile ilgili fikir sağlamasının yanı sıra yapılacak psikoterapi, çevre ve doğa eğitim uygulamalarına da birçok kolaylık oluşturacağı düşünülmüş; ayrıca ülkemizdeki konuyla ilgili alanyazın [eğitim, psikoloji, sosyal bilimler (coğrafya), fen bilimleri (biyoloji)] incelendiğinde böyle bir ölçeğin olmaması, bu çalışmayla birlikte alanyazının zenginleşeceği fikrini uyandırmıştır. Ölçeğin yapı geçerliliği farklı katılımcılar kullanarak doğrulayıcı faktör analizi (DFA) yapılmalıdır. DFA yapılırken tek boyutlu ve üç boyutlu modeller ayrı ayrı sınanarak uyum indeksi değerleri incelenmelidir.

Çalışmanın diğer amacında doğayla ilişkili olma ve öz-aşkınlık düzeyleri arasında ilişki olup olmadığını incelemek istenmiştir. Çalışma bulgusuna göre doğayla ilişkili olma ve öz-aşkınlık arasında pozitif ilişki bulunmaktadır. Öz-aşkınlık düzeyi yüksek olan bireylerin daha fazla doğayla içli dışlı olduğu söylenebilir. Bu ilişkide yaş değişkeninin önemli bir etken olduğu gözlenmiştir.

İlgili alanyazın incelendiğinde, doğayla ilişkili olma ile öznel iyi oluş ve mutluluk arasında pozitif (Nisbet, Zelenski, \& Murphy, 2011; Zelenski \& Nisbet, 2014; buna karşın doğayla ilişkili olma ve depresyon arasında negatif ilişkinin olduğunu (Zelenski \& Nisbet, 2014) aktaran çalışmalar bulunmaktadır. Buna paralel olarak öz-aşkınlığın iyi olma ile arasında pozitif (Haugan ve diğerleri, 2014; Runquist \& Reed, 2007); depresyonla ise negatif ilişkinin olduğu (Haugan \& Innstrand (2012) belirten çalışmalar bulunmaktadır. Bu bulgulardan hareketle hem doğayla ilişkili olma hem de öz-aşkınlık, psikolojik iyi olmanın önemli bileşenleri arasındadır. 
Dolayısıyla iki pozitif yapıya sahip kavramların birbiri arasında ilişki çıkması olasıdır. Bu çalışmayla birlikte bu olasılık desteklenmiş ve ilişkinin olduğu kanıtlanmıştır. Diğer taraftan kendini aşmış bir bireyin doğadan kendini soyutlaması öz-aşkınlık teorisinin özüne ters bir durumdur (Reed, 2008)

Doğayla ilişkili olma ve öz-aşkınlık ile ilgili ülkemiz alanyazınında çalışmalar çok kısıtlıdır. Fakat yurtdışı alanyazında her iki kavram da pozitif psikoloji bağlamında incelenmekte hatta psikolojik iyileştirme ve tedavi seanslarında önemli bir gösterge olarak ele alınmaktadır. Ülkemizde de psikoloji ve psikiyatri alanında özellikle klinik alanda bu iki kavram ile ilgili çalışmalar arttırılmalı: Örneğin, depresyon, stres, kaygı, mutluluk, yaşam doyumu gibi kavramlarla ilişki araştırılmalıdır.

\section{Kaynakça}

Alnıaçık, Ü., \& Koç F. (2009). Yeni Çevresel Paradigma Ölçeği ile üniversite öğrencilerinin çeoreye yönelik tutumlarının değerlendirilmesi. Balıkesir Üniversitesi Burhaniye MYO Bölgesel Kalkınma Kongresi (14 - 16 Kasım 2009) Burhaniye - Balıkesir.

Atalay İ. (2013). Doğa bilimleri sözlüğ̈̈. İzmir: Meta Basım ve Matbaacılık Büyüköztürk, Ş. (2012). Veri analizi el kitabı. Ankara: PegemA Yayıncılık.

Büyüköztürk, Ş., Akgün, Ö. E., Kahveci, A., \& Demirel, F. (2004). Güdülenme ve Öğrenme Stratejileri Ölçeğinin Türkçe formunun geçerlik ve güvenirlik çalışması. Kuram ve Uygulamada Eğitim Bilimleri, 4(2), 207-239.

Coward, D. D. (1996). Correlates of self-transcendence in a healthy population. Nursing Research, 45, 116-121.

Dunlap, R. E., Van Liere, K. D., Mertig, A. G., \& Jones, R. E. (2000). Measuring Endorsement of the New Ecological Paradigm: A Revised NEP Scale. Journal of Social Issues, 56(3), 425-442.

Erdoğan M. (2005). Çocuklara nasıl bir doğa eğitimi?: Çocuklar "Uygulamalı" diyor. Çocuklara nasıl bir doğa eğitimi? Çalıştayı, Ankara.

Franěk, M. (2012). Nature Relatedness Scale. Český překlad škály měřící spojení s př́rodou. Envigogika, 7(1), 1-10.

Gül, F. (2013). İnsan-doğa ilişkisi bağlamında çevre sorunları ve felsefe. Pamukkale Üniversitesi Sosyal Bilimler Enstitüsü Dergisi, 14, 17-21.

Haugan, G., \& Innstrand, S. T. (2012). The effect of self-transcendence on depression in cognitively intact nursing home patients. International Scholarly Research Notices. Article ID 301325.

Haugan G., Rannestad T., Hammervold R., Garasen H. \& Espnes G. A. (2014). The relationships between self-transcendence and spiritual 
well-being in cognitively intact nursing home patients. International Journal of Older People Nursing, 9(1), 65-78.

İzbırak, R. (1992). Coğrafya terimleri sözlüğü. İstanbul: MEB yayınları.

Köşger, N. (2013). İlkokul öğrencileri ve sınıf öğretmeni adaylarının doğaya ilişkin algıları ve sorumluluklarına yönelik düşünceleri. Turkish Studies - International Periodical for the Languages, Literature and History of Turkish or Turkic, 8(3), 341-355.

Levenson, M. R., Jennings, P. A., Aldwin, C. M., \& Shiraishi, R. W. (2005). Self- transcendence: conceptualizations and measurements. International Journal of Aging and Human Development, 60, 127-143.

Nisbet, E. K., \& Zelenski, J. M. (2013). The NR-6: a new brief measure of nature relatedness. Frontiers in Psychology, 4, 1-11.

Nisbet, E. K., Zelenski, J. M., \& Murphy, S. A. (2011). Happiness is in our nature: Exploring nature relatedness as a contributor to subjective well-being. Journal of Happiness Studies, 12(2), 303-322.

Nisbet, E. K., \& Zelenski, J. M. (2011). Underestimating nearby nature: Affective forecasting errors obscure the happy path to sustainability. Psychological Science, 22, 1101-1106.

Nisbet, E. K., Zelenski, J. M., \& Murphy, S. A. (2009). The Nature Relatedness Scale. Linking individuals' connection with nature to environmental concern and behavior. Environment and Behavior, 41(5), 715-740.

Nygren, B., Aléx, L., Jonsén, E., Gustafson, Y., Norberg, A., \& Lundman, B. (2005). Resilience, sense of coherence, purpose in life and selftranscendence in relation to perceived physical and mental health among the oldest old. Aging \& Mental Health, 9, 354-362.

Ozaner, S. (2005). Çocuklara nasıl bir doğa eğitimi verilmelidir? Çocuklara Nasıl Bir Doğa Eğitimi? Çalıştayı, Ankara.

Ramer, L., Johnson, D., Chan, L., \& Barrett, M. T. (2006). The effect of HIV/AIDS disease progression on spirituality and selftranscendence in a multicultural population. Journal of Transcultural Nursing, 17, 280-289.

Reed. G. P. (2008). The theory of self-transcendence. In Smith, M.J. \& Liehr, P.R., Middle range theory for nursing (pp.145-166). New York: Springer.

Reed. G. P. (1991a). Self-transcendence and mental health in oldest-old adults. Nursing Research, 40(1), 5-11.

Reed. G. P. (1991b). Toward a nursing theory of self-transcendence: Deductive reformulation using developmental theories. Advances in Nursing Science, 13(4), 64-77. 
Reed, P. G. (1989). Mental health of older adults. Western Journal of Nursing Research, 11, 143-163.

Reed, P. G. (1986). Developmental resources and depression in the elderly. Nursing Research, 35, 368-374.

Runquist, J. J., \& Reed, P. G. (2007). Self-transcendence and well-being in homeless adults. Journal of Holistic Nursing, 25(1), 5-13.

Sarıçam, H. (2015). Öz Aşkınlık Ölçeği Türkçe formunun psikometrik özellikleri. Eurasian Academy of Sciences Social Sciences Journal, 5, 2534.

Sarıçam, H. (2013). Öz-aşkınlık (Self-transcendence). İçinde. Ahmet Akın (Ed.), Güncel Psikolojik Kavramlar (Benlik), (ss.185-194). Sakarya: Sakarya Üniversitesi Eğitim Bilimleri Enstitüsü Yayınları.

Vanagas, R., \& Rakšnys, A. V. (2014). The dichotomy of self-actualization and self-transcendence. Verslo Sistemos ir Ekonomika Business Systems and Economics, 4(2), 196-203.

Zelenski, J. M., \& Nisbet, E. K. (2014). Happiness and feeling connected: The distinct role of nature relatedness. Environment and Behavior, 46(1), 323. 